\title{
Cleaning protocol of archaeological dental calculus: A methodological proposal for vegetable microremains analysis
}

\author{
Aldana Tavarone $^{1}$ | María de los Milagros Colobig ${ }^{2}$ | Esteban Passeggi ${ }^{2}$ | \\ Mariana Fabra ${ }^{1}$ (이
}

${ }^{1}$ Instituto de Antropología de Córdoba (IDACOR-CONICET), Facultad de Filosofía y Humanidades, Universidad Nacional de Córdoba (UNC), Córdoba, Argentina

${ }^{2}$ Centro de Investigaciones Científicas y Transferencia de Tecnología a la Producción (CICYTTP-CONICET), Facultad de Ciencia y Tecnología, Universidad Autónoma de Entre Ríos (UADER), Entre Ríos, Argentina

\section{Correspondence}

M. Fabra, IDACOR/Consejo Nacional de Investigaciones Científicas y Técnicas (CONICET), Laboratorio de Bioantropología, Museo de Antropología, Facultad de Filosofía y Humanidades, Universidad Nacional de Córdoba, Córdoba, CP. 5000, Argentina.

Email: marianafabra@gmail.com

Funding information

Agencia Nacional de Promoción Científica y Técnica (FONCYT), Grant/Award Number: PICT 2015 3155; Secretaría de Ciencia y Técnica, Universidad Nacional de Córdoba (2016-2017)

\begin{abstract}
Objectives: One of the major drawbacks involves the contamination produced during the sampling of dental calculus samples due to their manipulation with non-sterilized latex gloves containing maize starch. These gloves have been commonly used for the sampling, cleaning and conservation of archaeological materials. The objective of the present work is to propose a protocol for the cleaning of dental calculus samples that have been contaminated, allowing the removal of such material from the calculus surface. The application of this protocol guarantees the exogenous elements elimination without causing the loss of the archaeological material, since as it is a nondestructive and/or invasive cleaning method, it remains contained within the dental calculus which protects and guarantees its preservation.

Materials and methods: Fifty-seven fragments of dental calculus were recovered from several archaeological sites in the province of Córdoba, Argentina, dated by AMS between 4058 and $38714 \mathrm{C}$ years BP. A sample comprising 22 fragments larger than $2 \mathrm{~mm}$, which represent $38.59 \%$ of the total, were subjected to four cleaning stages through distilled and centrifugal water. As a control test, 10 fragments of human dental tartar were taken, known to have not been previously handled with powdered latex gloves.

Results and discussion: The results show significant differences between the four cleaning stages, representing an important reduction of modern starch grains adhered to the surface of archaeological samples of human dental calculus.
\end{abstract}

\section{KEYWORDS}

contamination, dental calculus, human skeletal remains, starch grains

\section{1 | INTRODUCTION}

The presence of the plant microremains in the archaeological record allows us to inquire about the subsistence strategies developed by human communities over time (Babot, 2007,2009, 2011; Babot and Apella, 2003; Colobig and Ottalagano, 2016; Gil-López, 2011; Heider and López, 2016; Korstanje and Babot, 2007; López, 2007; Musaubach, 2012,2017; Musaubach and Berón, 2017; among others).

Dental calculus is present in all human populations. Once the tooth erupts, the crown is covered by a thin organic layer (biofilm) that is formed from salivary proteins and gingival fluid. On the same, different microorganisms adhere that will end up forming the bacterial plaque (Marsh and Martin, 1999). The formation of dental calculus is produced by the mineralization of the same that is consolidated on the surface of the tooth during the life of the individual, forming a concrete matrix. During this process, plant micro-resins (silicophytoliths and starch grains), and other elements like sponge spicules, pollen grains, diatoms, and so forth are incorporated and retained between the successive layers of calcium phosphate crystals that are deposited on the enamel due to poor oral hygiene (Hillson, 1996; Lieverse, 1999; Musaubach, 2012; Warinner et al., 2014).

One of the major drawbacks in addressing the study of microremains from dental calculus is the contamination resulting from the use of latex gloves, frequently powdered with maize starch (Tavarone, Colobig, \& Fabra, 2016; Wadley, Lombard, \& Williamson, 2004), because can modify the original composition of the sample. At this 


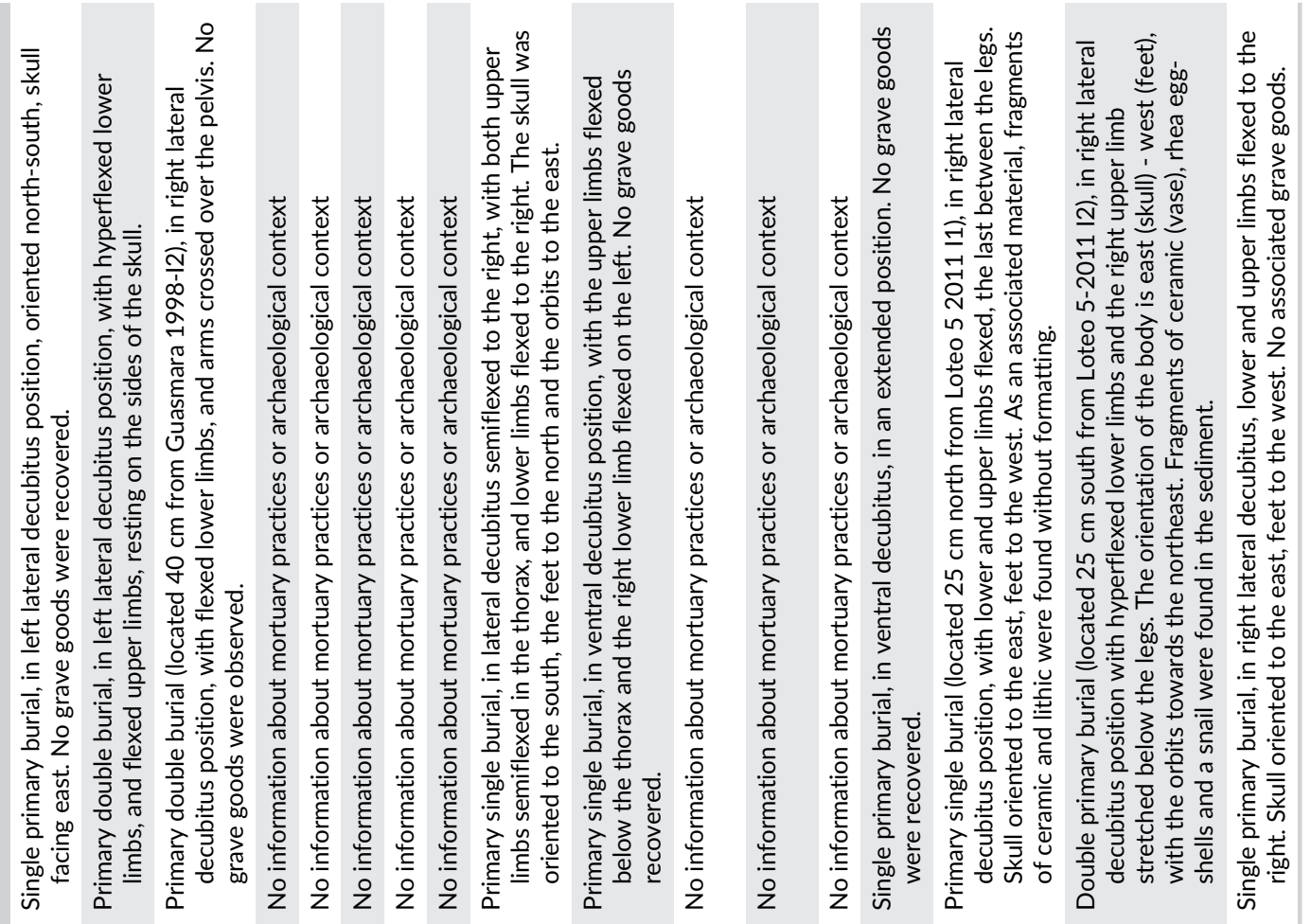
造

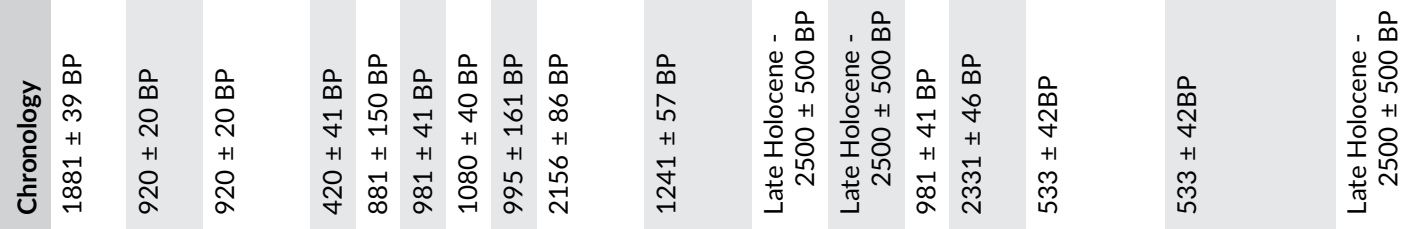

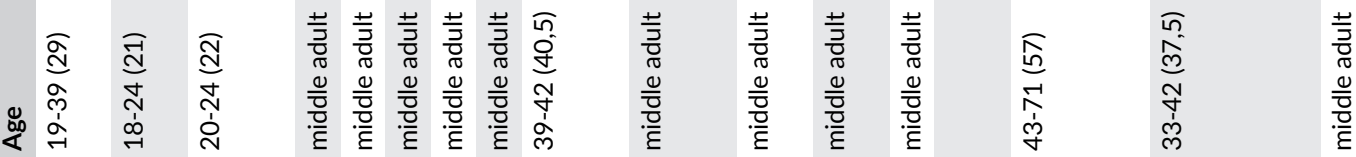

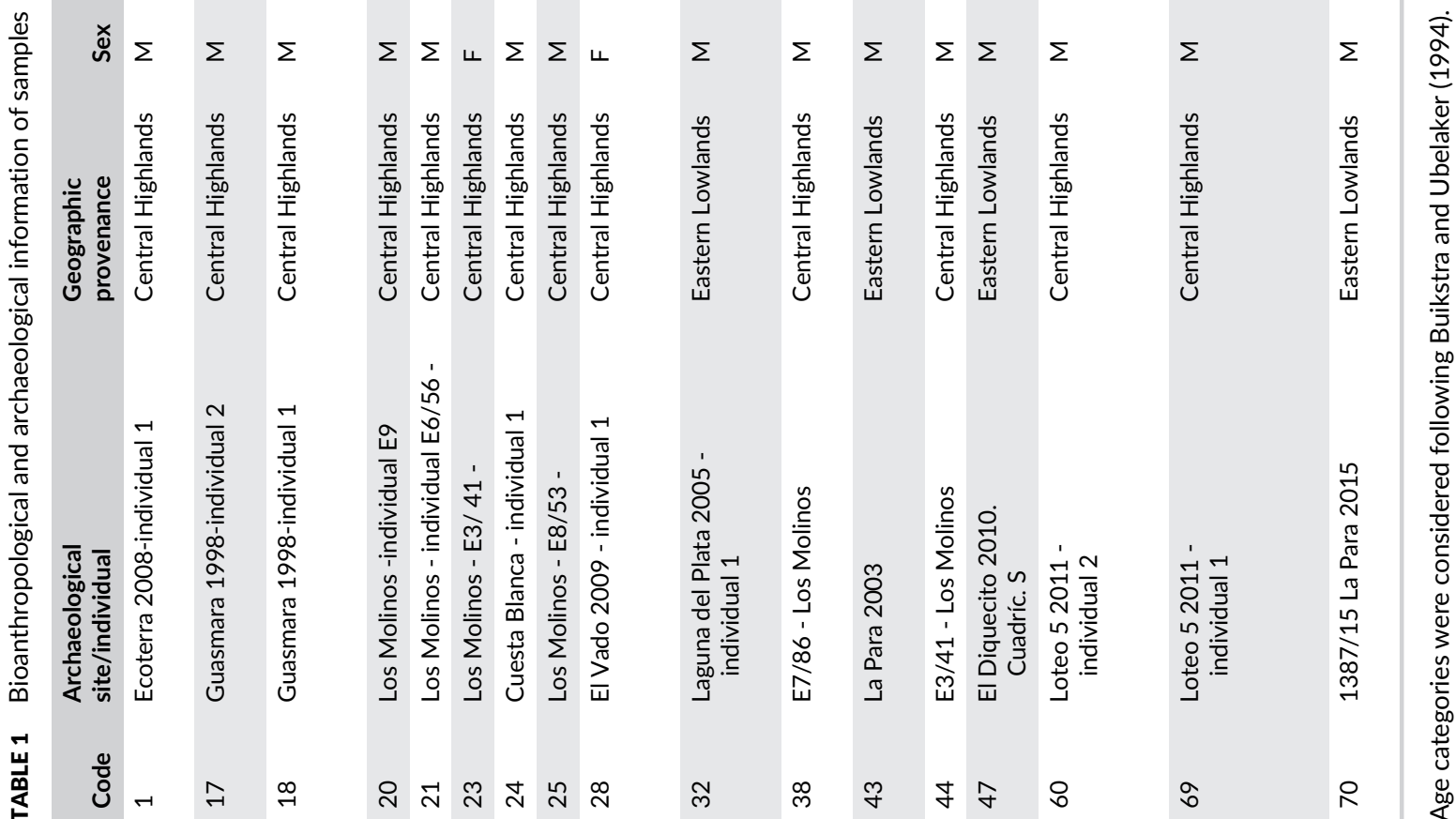


TABLE 2 Counts of starch grains present in each control

\begin{tabular}{|c|c|c|c|c|c|}
\hline \multirow{2}{*}{ Samples } & \multirow{2}{*}{ Before contamination } & \multicolumn{4}{|l|}{ After contamination } \\
\hline & & First Control-Count & Second Control-Count & Third Control-Count & Fourth Control-Count \\
\hline LR-TE-E5 1 & 0 & 7 & 3 & 0 & 0 \\
\hline LR-TE-E5 3 & 0 & 4 & 1 & 0 & 0 \\
\hline SVEP14 1 & 0 & 8 & 2 & 0 & 0 \\
\hline SVEP14 1 & 0 & 4 & 1 & 0 & 0 \\
\hline SVEP14 1 & 0 & 10 & 4 & 1 & 0 \\
\hline $915 / 1$ & 0 & 5 & 2 & 0 & 0 \\
\hline $915 / 2$ & 0 & 9 & 2 & 1 & 0 \\
\hline $915 / 3$ & 0 & 6 & 1 & 0 & 0 \\
\hline 10 samples & 0 starch grains & 70 starch grains & 21 starch grains & 3 starch grains & 0 starch grains \\
\hline
\end{tabular}

The letters and numbers observed in the "samples" column correspond to individuals from whom the sample was taken.

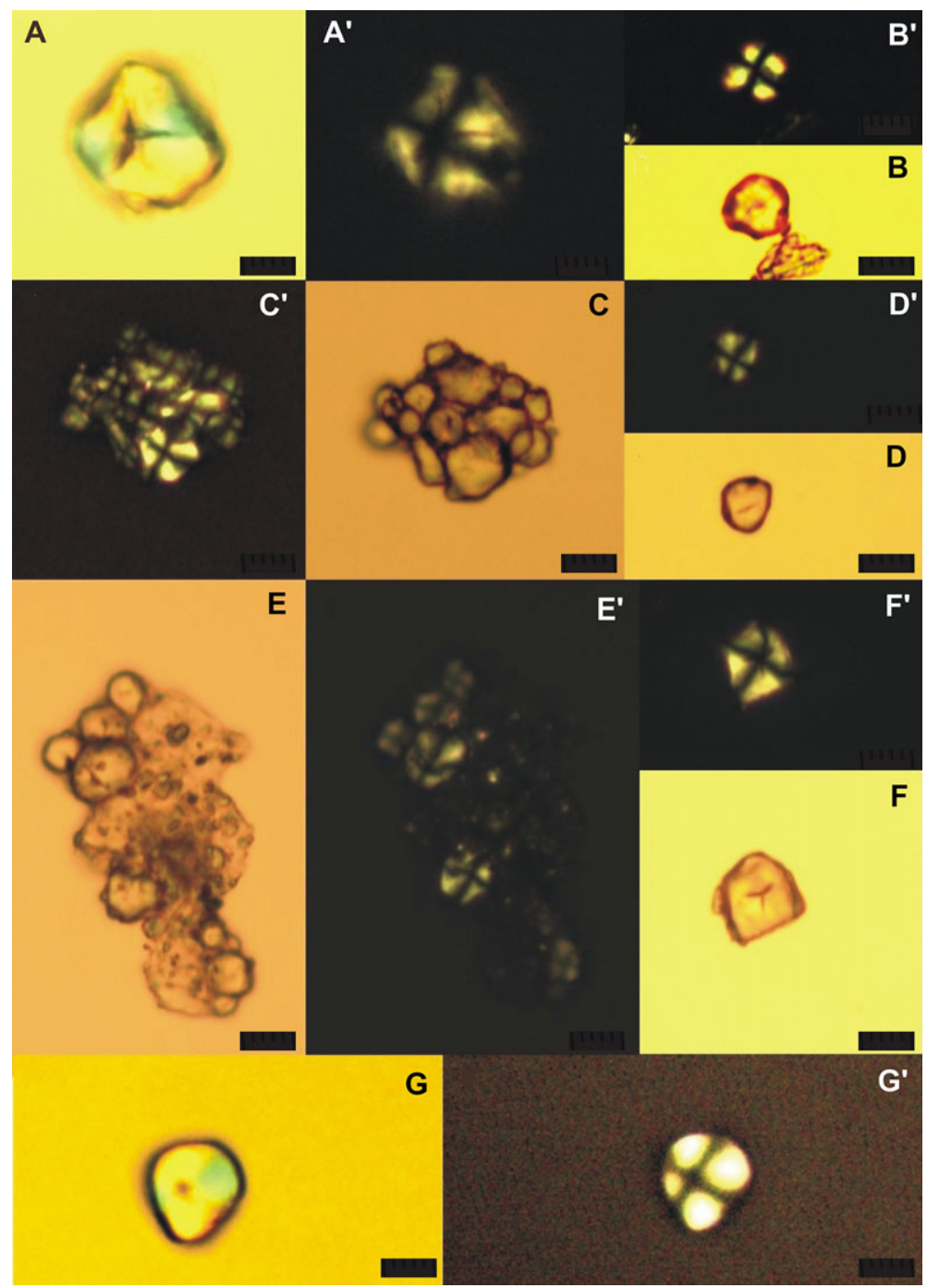

FIGURE 1 Starch grains observed in Control 1. A-A'. Grain of polygonal starch observed with polarized and normal light. B-B'.Grain of polyhedral starch with polarized and normal light. C-C'. Agglomerated starch grains, observed with polarized and normal light. D-D'. Oval starch grain observed with polarized and normal light. E-E'. Agglomerated starch grains, observed with polarized and normal light. F-F'. Grain of polygonal starch observed with polarized and normal light. G-G'. Oval starch grain observed with polarized and normal light. Scale: $20 \mu \mathrm{m}$ 
TABLE 3 Counts of starch grains present in each control

\begin{tabular}{|c|c|c|c|c|}
\hline Samples & $\begin{array}{l}\text { First } \\
\text { Control- } \\
\text { Count }\end{array}$ & $\begin{array}{l}\text { Second } \\
\text { Control- } \\
\text { Count }\end{array}$ & $\begin{array}{l}\text { Third } \\
\text { Control- } \\
\text { Count }\end{array}$ & $\begin{array}{l}\text { Fourth } \\
\text { Control- } \\
\text { Count }\end{array}$ \\
\hline $1-22 L$ & 18 & 4 & 1 & 0 \\
\hline $1-28 \mathrm{M}$ & 16 & 4 & 0 & 0 \\
\hline $17-28 M$ & 7 & 1 & 0 & 0 \\
\hline $18-2 B$ & 9 & 2 & 1 & 0 \\
\hline $20-3 M$ & 5 & 1 & 0 & 0 \\
\hline 21-19L & 17 & 5 & 2 & 0 \\
\hline $21-23 V$ & 13 & 7 & 3 & 0 \\
\hline $21-25 \mathrm{~V}$ & 10 & 4 & 2 & 0 \\
\hline $23-5 P$ & 6 & 2 & 0 & 0 \\
\hline $23-9 P$ & 8 & 1 & 1 & 0 \\
\hline $24-26 \mathrm{~V}$ & 12 & 3 & 2 & 0 \\
\hline $25-25 \mathrm{~V}$ & 10 & 3 & 0 & 0 \\
\hline 28-31B & 21 & 6 & 3 & 1 \\
\hline $32-8 V$ & 8 & 3 & 1 & 0 \\
\hline $38-20 D$ & 4 & 3 & 1 & 0 \\
\hline 43-19B & 6 & 4 & 2 & 1 \\
\hline 44-11B & 18 & 5 & 2 & 0 \\
\hline $47-23 B$ & 7 & 1 & 0 & 0 \\
\hline $60-32 M$ & 5 & 2 & 1 & 0 \\
\hline 69-17L & 7 & 0 & 0 & 0 \\
\hline 69-27B & 9 & 1 & 0 & 0 \\
\hline $70-28 \mathrm{~L}$ & 13 & 2 & 1 & 0 \\
\hline 22 samples & $\begin{array}{l}229 \text { starch } \\
\text { grains }\end{array}$ & $\begin{array}{c}64 \text { starch } \\
\text { grains }\end{array}$ & $\begin{array}{c}24 \text { starch } \\
\text { grains }\end{array}$ & $\begin{array}{r}3 \text { starch } \\
\text { grains }\end{array}$ \\
\hline
\end{tabular}

The first number corresponds to the individual from whom the sample was taken; the second corresponds to the tooth from which the tartar was extracted; the letter indicates the face of the tooth from which it was extracted. L: lingual, D: distal, M: mesial, P: palatine and B: buccal.

time the starch grains contained and protected inside the sample are released producing a mixture with those modern elements that were stuck on its surface.

The aim of this work is to provide methodological guidelines for the cleaning of dental calculus contaminated, thereby ensuring the production of reliable results.

\section{2 | MATERIAL AND METHODS}

The sample on which this work is based, was contaminated with powdered gloves. Since these samples are part of the museum collections, it is possible that the contamination came from previous manipulations. These grains adhered to the surface need to be eliminated, to ensure that only the grains contained into the dental calculus are part of the archaeological record, and the modern grains do not interfere with the final result.

Fifty-seven fragments of dental calculus were recovered from several archaeological sites in the province of Córdoba, Argentina, dated by AMS between 4058 and $38714 \mathrm{C}$ years BP (Table 1). For the selection of a statistically representative sample of the initial set, the simple random sampling method without replacement was used, obtaining a final sample comprising 22 fragments, larger than $2 \mathrm{~mm}$, which representing $38.59 \%$ of the total.

The 22 fragments were subjected to the same decontamination process consisting of four consecutive washing stages:

1. The calculus fragment was taken and placed in a $53 \mu \mathrm{m}$ mesh sieve. The material was rinsed with $\sim 10 \mathrm{~mL}$ of distilled water, trying to remove as much dust as possible. A drop of the surrounding liquid $(0.05 \mathrm{~mL})$ was then taken to perform a first control under the microscope.

2. The rinsed calculus was placed in a $50 \mathrm{~mL}$ centrifuge tube and filled into $25 \mathrm{~mL}$ with distilled water, which was taken to the Rolco model 2036 centrifuge for $10 \mathrm{~min}$ at $2000 \mathrm{rpm}$. After removal of the sample, one drop $(0.05 \mathrm{~mL})$ of distilled water was extracted from the floating material for a second control under the microscope, discarding the surplus liquid.

3. The sample was placed in a $1.5 \mathrm{~mL}$ Ependorf tube, the whole was filled with distilled water and again taken to the centrifuge for $10 \mathrm{~min}$ at $2000 \mathrm{rpm}$. Subsequently, the material was removed from the centrifuge, and a sample of liquid $(0.05 \mathrm{~mL})$ was taken for a third control.

4. A final rinse was carried out, renewing the distilled water and bringing the sample back to the centrifuge to repeat the process. Once the process was completed, a drop of water $(0.05 \mathrm{~mL})$ was collected for a fourth and final control.

For observations and counts, a Nikon Eclipse E 200 polarized light microscope was used, with $40 \times$ magnification. The microphotographs were taken with a Nikon camera attached to it. The descriptions of the starch grains were made according to the qualitative and quantitative guidelines and attributes proposed by Babot (2011); Babot and Apella (2003); Cortella and Pochettino, 1994; Korstanje and Babot (2007) and The International Code for Starch Nomenclature (ICSN-2011).

To test the protocol, 10 fragments of human dental tartar were taken, known to have not been previously handled with powdered latex glove. First, the fragments were rinsed with distilled water over a 53- $\mu \mathrm{m}$ mesh sieve, and a drop of the surrounding liquid was taken and observed under the microscope. In none of the cases starch elements were found in the preparations. The next step was to take the fragments and manipulate them with lightly powdered latex gloves $(N P \AA)$. The rinsing process was repeated and a drop of the recovered liquid was observed under the microscope. At this time starch grains of different shapes and sizes were observed in all the samples. The fragments, once contaminated, were subjected to the cleaning protocol proposed in this work, reaching complete cleaning of the samples (Table 2).

On the other hand, 10 nonsterile, powder-free disposable latex gloves were selected from the same box as those used during the manipulation of dental calculus, to conduct a survey about the morphology and size of the starch grains present in them. With a plastic spatula, both internal and external faces of the gloves were scraped 


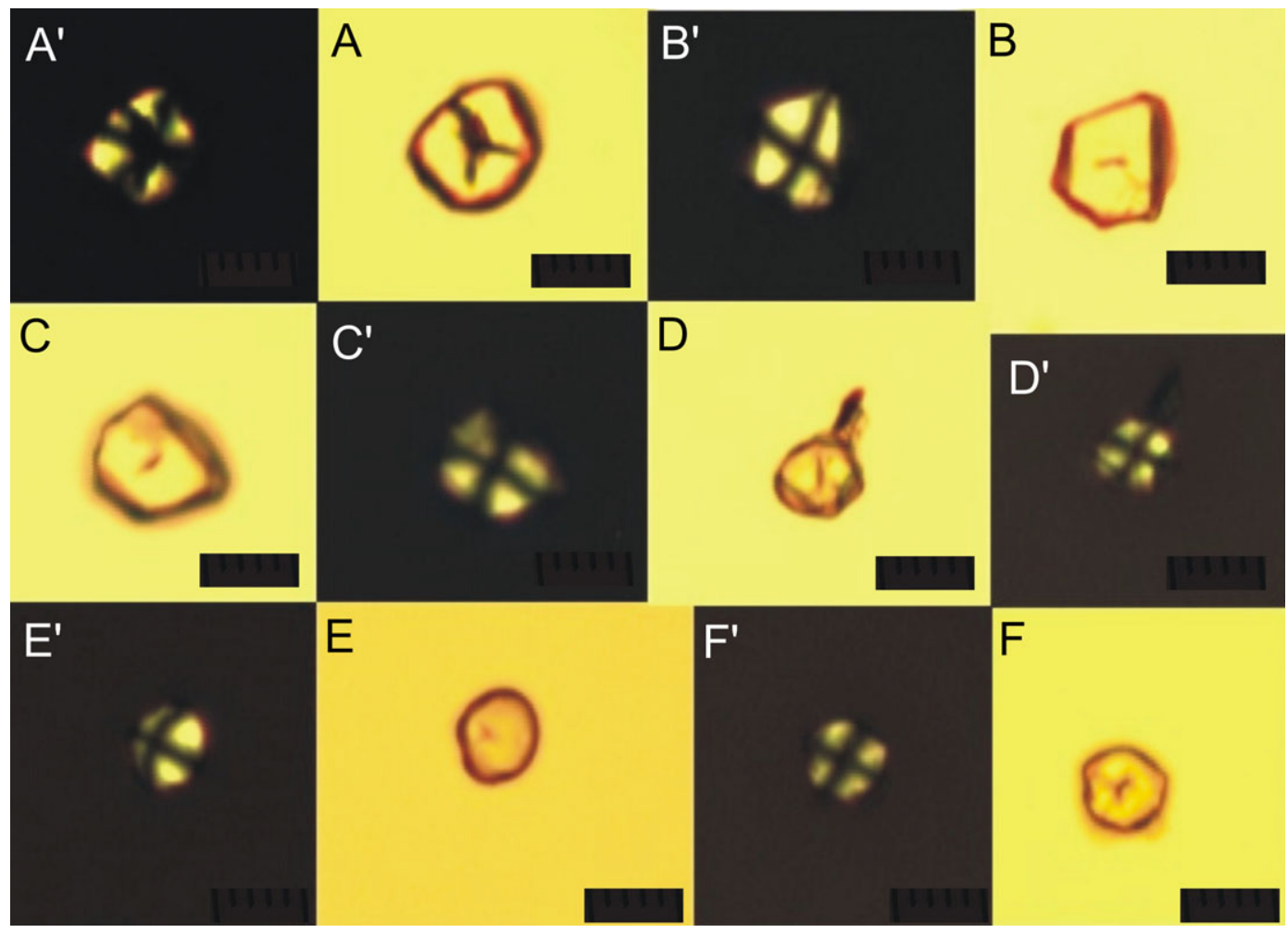

FIGURE 2 Starch grains observed in Control 2. A-A'. Grain of polygonal starch observed with polarized and normal light. B-B'. Grain of polygonal starch with polarized and normal light. C- $C^{\prime}$. Grain of polygonal starch with polarized and normal light.D-D'. Grain of polyhedral starch observed with polarized and normal light. E-E'. Oval starch grain observed with polarized and normal light. F-F'. Oval starch grain observed with polarized and normal light. Scale: $20 \mu \mathrm{m}$

directly on a slide using cedar oil as a medium of assembly (Colobig et al., 2016).

\section{3 | RESULTS}

\subsection{Control test}

No starch grains were observed in any of the controls tested before contamination. After contamination, the protocol was applied with the following results: first control 70 starches; second, 21 and third, only 3 grains were counted. The fourth and final rinse did not evidence these elements in the liquid observed (Table 2).

\subsection{Cleaning result}

During the first control, 229 starch grains were observed in 15 samples (Figure 1, Table 3).

During the second control, a total of 64 starch grains were observed (Figure 2, Table 3).
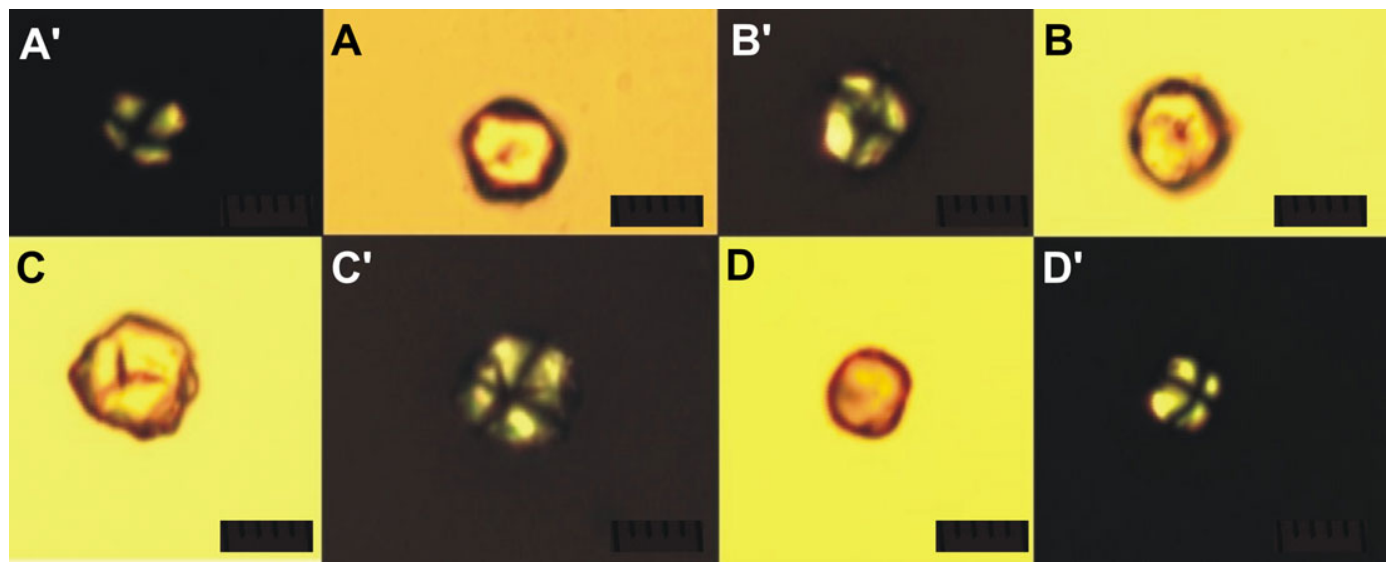

FIGURE 3 Starch grains observed in Control 3. A-A'. Oval starch grain observed with polarized and normal light. B-B'. Oval starch grain with polarized and normal light. C-C'. Grain of polygonal starch with polarized and normal light. D-D'. Grain of polyhedral starch observed with polarized and normal light. E-E'. Oval starch grain observed with polarized and normal light. Scale: $20 \mu \mathrm{m}$ 


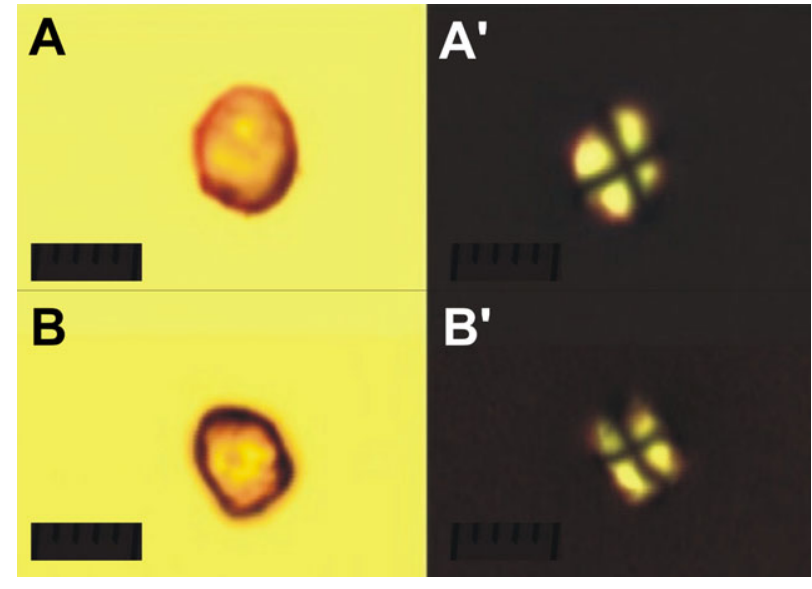

FIGURE 4 Starch grains observed in Control 4. A-A'. Oval starch grain observed with polarized and normal light. B-B'. Grain of polyhedral starch with polarized and normal light. Scale: $20 \mu \mathrm{m}$

During the third control, a total of 24 grains were found in 14 of the samples recovered (Figure 3, Table 3).

For the fourth and last control, it was possible to observe only the presence of 2 grains of starch in two of the samples surveyed (Figure 4, Table 3).

The total count of starch grains adhered to the surface of the intact dental calculus showed a remarkable decrease in relation to successive washes (Figure 5).

A nonparametric comparison test was applied for $k$ dependent samples (Friedman Test) under the null hypothesis $(\mathrm{HO})$ that "there are no differences in the counting of starch grains before and after the successive washes." Table 4 presents the statistics resulting from the test. The null hypothesis is rejected $(p<0.0001)$ and it is concluded that the differences in the control count of starch grains after the washings are significant.

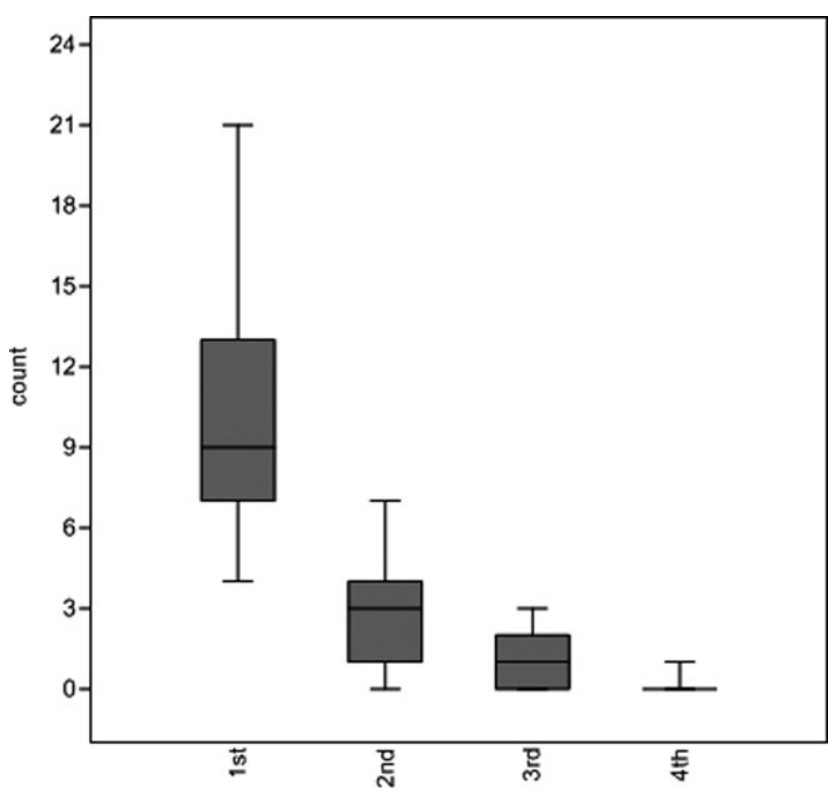

FIGURE 5 Boxplot of starch grains removed at each wash
TABLE 4 Friedman test

\begin{tabular}{lllll} 
Ranks & & & Test statistics & \\
\cline { 5 - 6 } \cline { 5 - 6 } & Mean rank & & N & 22 \\
First control & 4.00 & & Chi-Square & 63.1 \\
Second control & 2.93 & & df & 3 \\
Third control & 1.86 & & Asymp. Sig. & 0.000 \\
Fourth control & 1.20 & & &
\end{tabular}

\section{3 | Glove content analysis}

All of the observed preparations presented starch grains on both sides, although a greater amount of them were observed in those samples corresponding to the internal surfaces, which showed more agglomerated starch grains of different types and sizes, which ranged between 15 and $2 \mu \mathrm{m}$ (Colobig et al., 2016). As for the botanical affinities, there was a predominance of polygonal grains, with defined and circular fissures, attributable to Zea mays and oval grains, being mostly nondiagnostic (Colobig et al., 2016; Korstanje and Babot, 2007).

\section{DISCUSSION AND CONCLUSIONS}

The cleaning protocol proposed has allowed eliminating exogenous agents adhering to dental calculus of archaeological origin. The remarkable reduction of total starch grains present on the outer surface of the calculus, between the first and the fourth wash, shows the effectiveness of the protocol.

Moreover, according to the number of starch grains identified from the observation of the material collected from latex $N P \circledast$ gloves, it is possible to confirm that the internal surface of the gloves is the one with the highest amount of contaminating components. Although the external surface of the glove is the one that presents a lower amount of these contaminating elements, in direct contact with the archaeological material, it poses a high risk at the moment of manipulation with this type of product, as it was demonstrated during the control test. It has only been possible to identify starch grains assignable to Zea mays, mostly nondiagnostic, comparable to those found during the scraping of latex NP® gloves (Colobig et al., 2016).These diagnostic results differ from those found by Arriaza et al. (2015), where they identified the presence of starches corresponding to potato, rice and wheat.

The application of the guidelines presented here proves central when the manipulation of archaeological pieces has not been controlled and prior to the archaeobotanical analysis of the samples of dental calculus, to eliminate exogenous agents that may be present on their surface, thus minimizing the harmful effects of possible contamination. The methodology proposed here is innocuous for archaeological calculus samples and does not alter the material under study, since the cleaning is done with distilled water, which guarantees the removal only of the elements adhered on the surface of the fragment, without altering or modifying the original composition of microremains contained inside, and that are only released when the fragment is macerated, ensuring the results are trustworthy. Furthermore, we recommend avoid using latex gloves for the manipulation of any type of archaeological and bioarchaeological collection, and if necessary, use those that are dust free. 


\section{ACKNOWLEDGMENTS}

The authors thank Alejandro Zucol and Mariana Brea for their support and collaboration. They thank Nadia Tavarone and Carolina Mosconi for their English revision of the paper. They thank anonymous revisors for suggestions and contributions, which have significantly improved the work.

\section{ORCID}

Mariana Fabra (D) http://orcid.org/0000-0002-7269-6639

\section{REFERENCES}

Arriaza, B., Ogalde, J. P., Chacama, J., Standen, V., Huamán, L., \& Villanueva, F. (2015). Estudio de almidones en queros de madera del norte de Chile relacionados conel consumo de chicha durante el Horizonte inca. Estudios Atacameños. Arqueología yAntropología Surandinas, $50,59.84$

Babot, M. P. (2007). Granos de almidón en contextos arqueológicos: Posibilidades yperspectivas a partir de casos del Noroeste argentino. In B. Marconetto, M. P. del Babot, N. Oliszewski, Compiladores. Paleoetnobotánica del Cono Sur: estudios de casos ypropuestas metodológicas (pp. 95-125). Córdoba: Ferreyra Editor para el Museo de Antropología, Facultad de Filosofía y Humanidades. Universidad Nacional de Córdoba.

Babot, M. P. (2009). Procesamiento de tubérculos y raíces por grupos agropastoriles delnoroeste argentino prehispánico. Análisis de indicadores en residuos de molienda. In M. P. Babot (2011). Cazadores-recolectores de los andes centro-sur y procesamientovegetal. Una discusión desde la puna meridional argentina (ca. 7.000-3.200 años a.p.).Chungara, Revista de Arqueología Chilena 43, Número especial (pp 413-423).

Babot, M. P., \& Apella, M. C. (2003). Maize and bone: residues of grinding in Northwestern Argentina. Archaeometry, 45, 121-132.

Buikstra, J. \& Ubelaker, D. (1994). Standards for data collection from human skeletal remains. Proceedings of a seminar at the Field Museum of Natural History. Arkansas Archaeological Survey ResearchSeries Nro. 44.

Colobig, M., \& Ottalagano, F. (2016). Estudio arqueobotánico de los residuos orgánicosadheridos en alfarerías prehispánicas de la cuenca del Paraná medio. Arqueología, 22, 193-210.

Colobig, M., Tavarone, A., \& Fabra, M. (2016). Análisis Experimental de agentescontaminantes para la extracción de muestras arqueobotánicas (para la observación degranos de almidón)". Referencia: A. F. Zucol, N. I. Patterer, M. M. Colobig, \& E., Moya (Eds.). Taller de micropaleoetnobotánica. Relevancia de una red interdisciplinaria de Investigaciones en fitolitos y almidones (pp. 19-26). Argentina: Libro de Resúmenes. Diamante, Entre Ríos. ISSN 2525-0876.

Cortella, A. R., \& Pochettino, M. L. (1994). Starch grain analysis as a microscopicdiagnostic feature in the identification of plant material. Economic Botany, 48, 171-181.

Gil López, B. E. (2011). Fitolitos en cálculo dental de poblaciones Tempranas del vallegeográfico del río Cauca (500 a.C.- 500 d.C.). Aproximación a la paelodieta." Universidad Nacional de Colombia. Facultad de Ciencias Humanas. Maestría enAntropología (pp 161). Bogotá, Colombia. Inédita, 36:248-255.

Heider, G. \& López, L. (2016). El consumo de recursos vegetales silvestres en gruposCazadores Recolectores del Norte de Pampa Seca (San Luis y Córdoba, Argentina). Mundo de Antes $N^{\circ}$ 10. pp. 73-99 ISSN en línea 2362-325X.

Hillson, S. (1996). Dental anthropology. Cambridge: Cambridge University Press.

ICSN. The International Code for Starch Nomenclature. (2011). Available at: http://www.fossilfarm.org/ICSN/Code.html, June 15, 2014.

Korstanje, M. A., \& Babot, M. P. (2007). Microfossils characterization from South Andeaneconomic plants. In M. Madella \& D. Zurro (Eds.), Plants, people and places. Recentstudies in phytolith analysis (pp. 41-72). Oxford: Oxbow Books.

Lieverse, A. (1999). Diet and the aetiology of dental calculus. International Journal of Osteoarchaeology, 9, 219-232.

López, M. L. (2007). La Producción de Alimentos en las sociedades prehispánicas tardíasde Córdoba. Comechingonia, 1, 12-31. www. comechingonia.com.

Marsh, P., \& Martin, M. (1999). Oral microbiology, 4th ed. Oxford: Butterworth-Heinemann.

Musaubach, M. G. (2012). Potencialidad de estudios arqueobotánicos sobre Tártarodental de cazadores- recolectores de la Provincia de La Pampa, Argentina. Revista Argentina De Antropología Biológica, 14, 105-113.

Musaubach, M. G. (2017). Microrrestos vegetales en residuos arqueológicos. Propuestametodológica Para Su Estudio Arqueobotánico, Relaciones De La Sociedad Argentina de Antropologia, 42, 379-388.

Musaubach, M. G., \& Beron, M. A. (2017). Food residues as indicators of processe plantsin hunter-gatherers' pottery from La Pampa (Argentina). Vegetation History and Archaeobotany, 26, 111-123. DOI 10.1007/s00334-016-0581-z.Volume

Tavarone, A., Colobig, M \& Fabra, M. (2016). Metodología para el análisis demicrorrestos vegetales (silicofitolitos y almidones) contenidos en cálculos dentales derestos óseos humanos arqueológicos (Córdoba, Argentina). III Taller Nacional deBioarqueología y Paleopatología. La Plata.

Wadley, L., Lombard, M., \& Williamson, B. (2004). The first residue analysis blindtests: Results and lessons learned. Journal of Archaeological Science, 31, 1491-1501.

Warinner, C., Rodrigues, J. F. M., Vyas, R., Trachsel, C., Shved, N., Grossmann, J., ...Cappellini, E. (2014). Pathogens and host immunity in the ancient human oralcavity. Nature Genetics, 46, 336-344.

How to cite this article: Tavarone A, Colobig M, Passeggi E, Fabra M. Cleaning protocol of archaeological dental calculus: A methodological proposal for vegetable microremains analysis. Am. J. Phys. Anthropol. 2018;1. https://doi.org/10.1002/ajpa. $\underline{23630}$ 